\title{
PENGAWETAN BAGIAN LUNAK BATANG KELAPA BASAH DENGAN CARA TEKANAN
}

\section{(Preservation of Green Soft Tissue Coconut Wood by Pressure Metbod)}

\author{
Oleh/By:
}

\author{
Barly \& Didik A. Sudika
}

\section{ABSTRACT}

This paper deals with an experiment on the two-coconut varieties impregnated with boron compound preservative by pressure method. The green coconut wood samples were taken from the inner part (soft tissue) of the first, second and third logs of the trunk. Samples measuring $5 \mathrm{~cm} \times 10 \mathrm{~cm} \times 100 \mathrm{~cm}$ were impregnated with five percent boron compound solution using full cell process (FCP) and alternating pressure method (APM). Results indicated that all of the coconut varieties and position of log along the stem could be treated using pressure method. The study shows that retentions of preservative from $A P M\left(11,06 \mathrm{~kg} / \mathrm{m}^{3}\right.$ and $\left.9,44 \mathrm{~kg} / \mathrm{m}^{3}\right)$ is more effective than using $F C P\left(4,45 \mathrm{~kg} / \mathrm{m}^{3}\right.$ and $\left.4,74 \mathrm{~kg} / \mathrm{m}^{3}\right)$ in tall and bybrid coconut varieties.

Keywords: Preservation, soft and green coconut wood, pressure method.

\section{ABSTRAK}

Tulisan ini mengemukakan hasil penelitian metode tekanan pada dua varietas kelapa dengan bahan pengawet senyawa boron. Bagian lunak batang kelapa basah pada dolok kesatu, kedua dan ketiga berukuran $5 \mathrm{~cm} \times 10 \mathrm{~cm} \times 100 \mathrm{~cm}$ diawetkan dengan cara proses sel penuh (FCP) dan metode tekan berganti (APM). Hasil penelitian menunjukkan bahwa semua varietas dan letak dolok dalam batang kelapa dapat diawetkan dengan cara tekanan. Dari penelitian ini dapat diketahui bahwa retensi bahan pengawet yang dihasilkan dengan cara tekan berganti (APM) $(11,06$ $\mathrm{kg} / \mathrm{m}^{3}$ dan $\left.9,44 \mathrm{~kg} / \mathrm{m}^{3}\right)$, berbeda dengan yang dihasilkan dengan cara sel penuh (FCP) $\left(4,45 \mathrm{~kg} / \mathrm{m}^{3}\right.$ dan $4,74 \mathrm{~kg} / \mathrm{m}^{3}$ ) pada kelapa dalam dan kelapa hibrida.

Kata kunci: Pengawetan, bagian lunak dan basah batang kelapa, metode tekanan. 


\section{PENDAHULUAN}

Berbeda dengan kayu pada umumnya batang kelapa memiliki sel pembuluh yang berkelompok (vascular bundles) yang menyebar lebih rapat pada bagian tepi dari pada bagian tengah serta pada bagian bawah dan atas batang. Hal itu mengakibatkan kayu gergajian kelapa memiliki kekuatan yang berbeda-beda (Sulc, 1981). Palomar (1983) menyebutkan bahwa batang kelapa memiliki keawetan yang rendah, mudah diserang organisme perusak kayu seperti jamur dan serangga. Bagian keras batang kelapa yang tidak diawetkan dan dipasang ditempat terbuka langsung berhubungan dengan tanah maksimum dapat bertahan tiga tahun. Sedangkan untuk bagian lunak hanya beberapa bulan saja.

Menurut Martawijaya dan Barly (1982) ada empat faktor utama yang berpengaruh terhadap sifat keterawetan kayu, yaitu jenis kayu, keadaan kayu, metode pengawetan dan bahan pengawet yang dipakai. Berdasarkan pertimbangan di atas dalam penelitian ini digunakan bahan pengawet boron dengan cara tekanan. Bahan pengawet boron efektif terhadap serangga bubuk kayu kering meskipun dengan konsentrasi rendah. Konsentrasi $0,12 \%$ setara asam borat sudah cukup efektif untuk mencegah serangan bubuk kering Lictus spp. dan penggunaan larutan satu persen boraks dengan absorpsi $6-7 \mathrm{~kg} / \mathrm{m}^{3}$ dapat mencegah serangan Cryptotermes (Findlay, 1959). Menurut Richardson (1978) bahan pengawet boron dengan konsentrasi yang tepat dapat mencegah serangan jamur pewarna, meskipun kurang efektif terhadap kapang buluk (moulds) seperti Penecillium $s p$. dan Trichoderma spp. Spesifikasi untuk kayu bangunan yang akan dipakai di daerah tropis harus mengandung asam borat sebesar $8 \mathrm{~kg} / \mathrm{m}^{3}$ (Anonim, 1962). Retensi sebesar itu mampu mencegah serangan rayap, serangga dan jamur perusak kayu sedangkan penetrasinya harus mencapai 75 persen tebal kayu.

Penelitian ini bertujuan untuk mengetahui pengaruh cara pengawetan bagian lunak batang kelapa basah menggunakan metode APM dan FCP dengan bahan pengawet senyawa boron. Sasarannya adalah untuk mendapatkan cara pengawetan yang dapat menghasilkan retensi dan penetrasi sesuai persyaratan standar.

\section{BAHAN DAN METODE}

Batang kelapa yang digunakan dalam penelitian berjumlah empat pohon dari dua varietas, yaitu kelapa dalam dan kelapa hibrida. Masing-masing varietas disediakan dua pohon, berumur 19 tahun, yang diambil dari Balai Penelitian Kelapa Parungkuda, Sukabumi. Dari setiap pohon diambil enam meter dari pangkal dan dibagi menjadi tiga, dolok pertama, kedua dan ketiga dengan panjang masing-masing dua meter. Dolok digergaji dengan cara mengambil bagian tengahnya dan dijadikan balok berukuran 11 $\mathrm{cm} \times 11 \mathrm{~cm} \times 200 \mathrm{~cm}$. Pembuatan contoh uji dilakukan dengan cara balok dibelah dua dan diserut halus permukaannya menjadi ukuran $5 \mathrm{~cm} \times 10 \mathrm{~cm} \times 200 \mathrm{~cm}$. Pengambilan contoh uji untuk keperluan penetapan kadar air dilakukan dengan cara memotong balok tepat di bagian tengah pada arah memanjang setebal satu $\mathrm{cm}$. Penetapan kadar air dilakukan dengan cara oven pada suhu $105 \pm 2{ }^{\circ} \mathrm{C}$. Sisa penetapan kadar air digunakan 
untuk menetapkan berat jenis. Pola pengambilan contoh uji dapat dilihat pada Gambar 1. Pada setiap varietas, pada setiap ketinggian dan setiap metode pengawetan disediakan empat ulangan sehingga jumlah contoh uji seluruhnya berjumlah 48 batang.

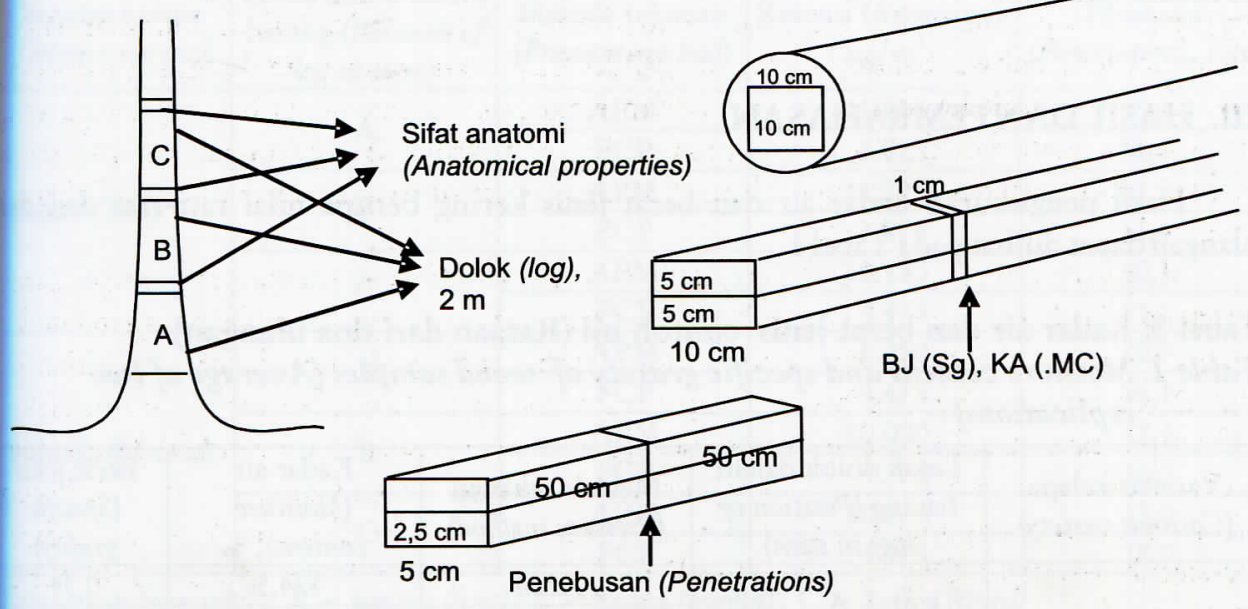

Gambar 1. Pola pembuatan contoh uji kayu Figure 1. Cutting patterm for wood sample

Sebagai bahan pengawet digunakan garam boron komersial yang mempunyai komposisi bahan aktif sebagai berikut: $\mathrm{H}_{3} \mathrm{BO}_{3} 35,52 \%, \mathrm{Na}_{2} \mathrm{~B}_{4} \mathrm{O}_{7} 35,52 \%$, dan metaborat 28,4\% (Anonim, 2004). Bahan pengawet tersebut dilarutkan dalam air dengan konsentrasi $5 \%(\mathrm{w} / \mathrm{v})$ untuk selanjutnya dipakai mengawetkan contoh uji pada suhu kamar dengan mengunakan cara vakum-tekan, yaitu proses sel penuh (full cell process) dan tekanan berganti (Alternating Pressure Method). Bagan pengawetan yang digunakan sebagai berikut :-vakum awal $650 \mathrm{~mm} \mathrm{Hg}$ selama 15 menit, - tekanan hidraulik $10 \mathrm{~atm}$ selama 60 menit, -vakum akhir $650 \mathrm{~mm} \mathrm{Hg}$ selama 15 menit. Pada proses tekanan berganti pelepasan dan pengulangan tekanan berulang setiap 15 menit, dengan lama waktu pengawetan sama seperti pada vakum-tekan. Retensi garam kering dinyatakan dalam $\mathrm{kg} / \mathrm{m}^{3}$ dihitung berdasarkan penimbangan berat contoh uji sebelum dan sesudah pengawetan. Contoh uji yang sudah diawetkan selanjutnya diangin-anginkan dalam ruangan sampai mencapai kadar air kering udara. Untuk keperluan pengukuran penembusan (penetration) bahan pengawet, contoh uji dibelah dua tepat di bagian tengah ke arah memanjang. Daerah penembusan dapat dilihat dengan jelas menggunakan larutan curcumin dalam alkohol yang merupakan pereaksi untuk uji boron. Pengukuran dilakukan pada dua sisi tepat dibagian tengah batang. Dalamnya penembusan bahan pengawet dinyatakan dalam $\mathrm{mm}$ yang merupakan nilai rata-rata dari empat ulangan. Analisa data untuk melihat pengaruh varietas kelapa, letak dolok dalam varietas yang 
sama serta metode pengawetan dalam dolok pada masing-masing varietas terhadap penetrasi dan retensi bahan pengawet menggunakan rancangan klasifikasi tersarang (Nested classification) (Steel \& Torrie, 1989). Apabila hasilnya terdapat perbedaan yang nyata, maka harga rata-ratanya dibandingkan dengan nilai beda nyata jujur menggunakan prosedur Duncan.

\section{HASIL DAN PEMBAHASAN}

Hasil pengukuran kadar air dan berat jenis kering berupa nilai rata-rata dari dua ulangan dapat dilihat pada Tabel 1.

Tabel 1. Kadar air dan berat jenis contoh uji (Rataan dari dua ulangan)

Table 1. Moisture content and specific gravity of wood samples (Average of two replications)

\begin{tabular}{|c|c|c|c|c|}
\hline $\begin{array}{l}\text { Varietas kelapa } \\
\text { (Coconut variety) }\end{array}$ & $\begin{array}{l}\text { Letak dolok dalam } \\
\text { batang (Position of } \\
\text { logs in stem) }\end{array}$ & $\begin{array}{l}\text { Metode tekanan } \\
\text { (Pressure method) }\end{array}$ & $\begin{array}{c}\text { Kadar air } \\
\text { (Moisture } \\
\text { content), \% } \\
\end{array}$ & $\begin{array}{c}\text { Berat jenis } \\
\text { (Specific } \\
\text { grafity) } \\
\end{array}$ \\
\hline \multirow{6}{*}{ Dalam (Tall) } & \multirow{2}{*}{ A } & APM & 124,5 & 0,39 \\
\hline & & FCP & 286,0 & 0,27 \\
\hline & \multirow{2}{*}{ B } & APM & 126,0 & 0,42 \\
\hline & & FCP & 240,0 & 0,28 \\
\hline & \multirow{2}{*}{$\mathrm{C}$} & APM & 128,0 & 0,42 \\
\hline & & FCP & 306,0 & 0,33 \\
\hline \multirow{6}{*}{ Hibrida (Hybrid) } & \multirow{2}{*}{ A } & APM & 72,5 & 0,54 \\
\hline & & FCP & 165,5 & 0,35 \\
\hline & \multirow{2}{*}{ B } & APM & 122,0 & 0,40 \\
\hline & & FCP & 243,0 & 0,32 \\
\hline & \multirow{2}{*}{$\mathrm{C}$} & $\mathrm{APM}$ & 95,5 & 0,40 \\
\hline & & FCP & 317,5 & 0,41 \\
\hline
\end{tabular}

Keterangan (Remarks) : A = kesatu (first); B = kedua (second), C = ketiga (third)

$\mathrm{APM}=$ Alternating Pressure Method, $\mathrm{FCP}=$ Full Cell Process

Pada Tabel 1 dapat diketahui bahwa contoh uji masih basah dengan kadar air bervariasi antara $72,5317,5 \%$ atau rata-rata $169 \%$ dan berat jenis bervariasi antara $0,27-0,54$ atau rata-rata 0,40 .

Hasil pengukuran retensi dan penetrasi bahan pengawet boron berupa nilai rata-rata dari empat ulangan pada dua varietas kelapa dengan tiga letak pada batang tercantum pada Tabel 2 dan sidik ragam masing-masing tercantum pada Tabel 3.

Pada Tabel 2 dan Tabel 3 dapat dilihat bahwa varietas kelapa berpengaruh sangat nyata terhadap penetrasi tetapi tidak berpengaruh nyata terhadap retensi bahan pengawet. Penetrasi bahan pengawet pada kelapa hibrida $(14,5 \mathrm{~mm})$ berbeda dibandingkan dengan penetrasi pada kelapa dalam $(11,0 \mathrm{~mm})$. Namun demikian kedua nilai penetrasi yang dihasilkan telah memenuhi persyaratan standar (Anonim, 1999). 
Tabel 2. Nilai retensi dan penetrasi bahan pengawet boron (Rataan dari empat ulangan)

Table 2. Retention and penetration value of boron preservative (Average of four replications)

\begin{tabular}{|c|c|c|c|c|}
\hline $\begin{array}{l}\text { Varietas kelapa } \\
\text { (Coconut variety) }\end{array}$ & $\begin{array}{l}\text { Letak dolok dalam } \\
\text { batang (Position of } \\
\text { log in stem) }\end{array}$ & $\begin{array}{l}\text { Metode tekanan } \\
\text { (Pressure method) }\end{array}$ & $\begin{array}{c}\text { Retensi (Retention), } \\
\mathrm{kg} / \mathrm{m}^{3}\end{array}$ & $\begin{array}{c}\text { Penetrasi } \\
\text { (Penetration), mm }\end{array}$ \\
\hline \multirow{6}{*}{ Dalam (Tall) } & \multirow{2}{*}{ A } & APM & 11.825 & 10,6 \\
\hline & & FCP & 5.025 & 11,1 \\
\hline & \multirow{2}{*}{ B } & APM & 11.225 & 11,9 \\
\hline & & FCP & 3.875 & 11,4 \\
\hline & \multirow{2}{*}{$\mathrm{C}$} & APM & 10.150 & 10,3 \\
\hline & & FCP & 4.475 & 11,1 \\
\hline \multirow{6}{*}{ Hibrida (Hybrid) } & \multirow{2}{*}{ A } & APM & 8.250 & 10,9 \\
\hline & & FCP & 4.475 & 16,3 \\
\hline & \multirow{2}{*}{ B } & APM & 10.000 & 12,4 \\
\hline & & FCP & 4.775 & 16,3 \\
\hline & \multirow{2}{*}{ C } & APM & 10.075 & 13,0 \\
\hline & & FCP & 4.975 & 18,0 \\
\hline
\end{tabular}

Keterangan (remarks): $\mathrm{A}=$ kesatu (first); $\mathrm{B}=$ kedua (second); $\mathrm{C}=$ ketiga (third)

APM $=$ Alternating Pressure Method, FCP $=$ Full Cell Proccess

Tabel 3. Sidik ragam retensi dan penetrasi bahan pengawet senyawa boron Table 3. Analysis of variance for retention and penetration of boron preservative

\begin{tabular}{|c|c|c|c|c|c|}
\hline \multirow{2}{*}{$\begin{array}{l}\text { Sumber variasi } \\
\text { (Source of variation) }\end{array}$} & \multirow{2}{*}{$\begin{array}{l}\mathrm{Db} \\
(d f)\end{array}$} & \multicolumn{2}{|c|}{$\begin{array}{l}\text { Kuadrat tengah } \\
\text { (Mean square) }\end{array}$} & \multicolumn{2}{|c|}{$\mathrm{F}_{\text {hitung }}\left(F_{\text {calculatect }}\right), 0,05$} \\
\hline & & $\begin{array}{c}\text { Retensi } \\
\text { (Retention) }\end{array}$ & $\begin{array}{c}\text { Penetrasi } \\
\text { (Penetration) }\end{array}$ & $\begin{array}{c}\text { Retensi } \\
\text { (Retention) }\end{array}$ & $\begin{array}{c}\text { Penetrasi } \\
\text { (Penetration) }\end{array}$ \\
\hline $\begin{array}{l}\text { Varietas kelapa (Coconut } \\
\text { variety) }\end{array}$ & 1 & 5,38223 & 276,76041 & 5,55 & $20,83^{* *}$ \\
\hline $\begin{array}{l}\text { Metode tekanan dalam varietas } \\
\text { yang sama (Pressure method } \\
\text { in the same coconut variety) }\end{array}$ & 2 & 197,28916 & 135,88542 & $90,46 * *$ & 22,96 \\
\hline $\begin{array}{l}\text { Letak dolok pada batang dalam } \\
\text { varietas dan metode tekan yang } \\
\text { sama (Location of logs in the } \\
\text { same variety and pressure } \\
\text { method) }\end{array}$ & 8 & 2,180833 & 5,916666 & $2,25^{*}$ & 0,44 \\
\hline Ulangan (Replication) & 36 & 0,9685426 & 13,281250 & & \\
\hline Jumlah (Total) & 47 & 9,622868 & 18,01569 & & \\
\hline
\end{tabular}

Sedangkan retensi bahan pengawet yang dihasilkan pada kelapa hibrida $\left(7,091 \mathrm{~kg} / \mathrm{m}^{3}\right)$ tidak berbeda dengan retensi pada kelapa dalam $\left(7,762 \mathrm{~kg} / \mathrm{m}^{3}\right)$. Letak dolok pada batang dalam varietas dan metode tekanan yang sama berbeda nyata terhadap retensi tetapi tidak berbeda nyata terhadap penetrasi. Retensi yang dicapai pada kelapa dalam 
cenderung menurun berturut-turut pada dolok pertama, kedua, dan ketiga, yaitu 8,452, 7,550 dan $7,312 \mathrm{~kg} / \mathrm{m}^{3}$. Sedangkan pada kelapa hibrida retensi yang dicapai cenderung meningkat berturut-turut pada dolok pertama, kedua, dan ketiga, yaitu 6,362, 7,387 dan $7,525 \mathrm{~kg} / \mathrm{m}^{3}$. Perbedaan tersebut mungkin disebabkan oleh perbedaan kadar air dan kerapatan contoh uji (Tabel 1).

Metode pengawetan dalam varietas yang sama berpengaruh sangat nyata terhadap retensi tetapi tidak berpengaruh nyata terhadap penetrasi bahan pengawet. Retensi yang dicapai dengan metode APM baik kelapa dalam $\left(11,066 \mathrm{~kg} / \mathrm{m}^{3}\right)$ maupun pada kelapa hibrida $\left(9,441 \mathrm{~kg} / \mathrm{m}^{3}\right)$ atau rata-rata $10,250 \mathrm{~kg} / \mathrm{m}^{3}$ berbeda dengan retensi yang dicapai metode FCP baik pada kelapa dalam $4,458 \mathrm{~kg} / \mathrm{m}^{3}$ maupun pada kelapa hibrida 4,741 $\mathrm{kg} / \mathrm{m}^{3}$ atau rata-rata $4,599 \mathrm{~kg} / \mathrm{m}^{3}$. Nilai beda nyata jujur retensi bahan pengawet pada tingkat nyata lima persen $\left(\mathrm{W}_{0,05}\right)$ sebesar $5,22 \mathrm{~kg} / \mathrm{m}^{3}$ pada metode tekanan dalam varietas yang sama.

Atas dasar persyaratan retensi asam borat sebesar $8 \mathrm{~kg} / \mathrm{m}^{3}$ (Anonim,1962), hasil perhitungan secara stechiometri atau perbandingan bobot $\mathrm{B}_{2} \mathrm{O}_{3}$ terhadap bahan pengawet yang digunakan dalam penelitian ini diperoleh nilai $6,28 \mathrm{~kg} / \mathrm{m}^{3}$. Nilai retensi sebesar itu sudah dapat dicapai dengan menggunakan metode APM yaitu $11,06 \mathrm{~kg} / \mathrm{m}^{3}$ (kelapa dalam) dan $9,44 \mathrm{~kg} / \mathrm{m}^{3}$ (kelapa hibrida), tetapi belum cukup dengan mengunakan metode FCP yaitu $4,45 \mathrm{~kg} / \mathrm{m}^{3}$ (kelapa dalam) dan $4,74 \mathrm{~kg} / \mathrm{m}^{3}$ (kelapa hibrida). Retensi yang dihasilkan metode APM dua kali lebih besar dari retensi yang dihasilkan metode FCP. Hasil itu menunjukkan bahwa metode APM dapat digunakan untuk mengawetkan bagian lunak batang kelapa basah, sesuai Anonim (1994). Sedangkan pengaruh letak dolok pada batang dalam varietas dan metode tekanan yang sama menghasilkan retensi yang berbeda tetapi secara keseluruhan di atas standar $6,28 \mathrm{~kg} / \mathrm{m}^{3}$ sehingga tidak perlu dikelompokkan dalam praktek pengawetannya.

\section{KESIMPULAN}

1. Bagian lunak batang kelapa dapat diawetkan dengan cara tekanan menggunakan bahan pengawet boron.

2. Pengawetan dengan metode tekan berganti (Alternating Pressure Method) memakai bagan yang digunakan dalam penelitian ini telah dapat memenuhi persyaratan retensi dan penetrasi sesuai spesifikasi bagi kayu bangunan perumahan dan gedung, sedangkan untuk pengawetan dengan metode sel-penuh (Full Cell Process) bagan pengawetan harus disesuaikan, karena hasilnya belum memenuhi persyaratan standar.

3. Letak dolok pada batang berpengaruh terhadap retensi bahan pengawet, tetapi sudah memenuhi persyaratan standar sehingga tidak perlu dipisahkan dalam pengawetannya. 


\section{DAFTAR PUSTAKA}

Anonim. 1962. Timber preservative. Borax Consolidated Limited. London.

. 1994. Environmental aspects of industrial wood preservation. Technical Report Series No.20. UNEP Programme, Paris. p.72.

. 1999. Pengawetan kayu untuk perumahan dan gedung. Badan Standardisasi Nasional, Jakarta. SNI.03-5010.1.1999.

.2000. Peluang investasi pengolahan batang kelapa dan strategi peremejaan kelapa di Indonesia. Lokakarya Pemanfaatan Batang Kelapa, tanggal 26 September 2000 di Jakarta. Direktorat Jendral Perkebunan, Deptan. Jakarta.

. 2004. Pestisida untuk pertanian dan kehutanan. Direktorat Pupuk dan Pestisida. Departemen Pertanian. 399 pp. Jakarta.

Carr, D. R. 1962. Timborised timber. Borax Consolidated Limited. London.

Findlay, W.P.K. 1959. Boron compound for the preservation of timer against fungi and insect. German Wood Research Assosiation $6^{\text {th }}$. Wood Protection Congres, Juli 1959.

Martawijaya, A. dan Barly. 1982. Resistensi kayu Indonesia terhadap impregnasi dengan bahan pengawet CCA. Pengumuman No. 5. Balai Penelitian Hasil Hutan, Bogor.

Palomar, R.N. and V. K. Sulc. 1983. Preservative treatment and performance of coconut palm timber. Timber Utilization Devision, PCA Zamboanga Research Center, Coconot Research and Deveopment Project.

Richardson, B.A. 1978. Wood preservation. The Construction Press., New York. London.

Sulc, V.K. 1984. Coconut palm wood utilization. Tecnical Documen No.2. UNDP-FAO of the United Nation. Zamboanga, Philipines, September 1984.

Steel, R.G.D. dan J.H. Torrie. 1991. Prinsip prosedur statistik. Terjemahan. Gramedia, Jakarta. 